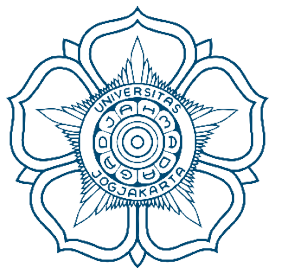
Judul Naskah : REKONSTRUKSI HUKUM ATAS POLA PENANGANAN PELANGGARAN ASAS NETRALITAS PEGAWAI NEGERI SIPIL

Nama Penulis : Tedi Sudrajat dan Sri Hartini

MIMBAR HUKUM

$\begin{array}{ll}\text { DOI } & : \text { http://doi.org/10.22146/jmh.26233 } \\ \text { Penerbit } & : \text { Fakultas Hukum Universitas Gadjah Mada } \\ \text { URL } & : \text { jurnal.ugm.ac.id/jmh } \\ \text { E Issn } & : 2443-0994 \\ \text { P Issn } & : 0852-100 \mathrm{x}\end{array}$




\title{
REKONSTRUKSI HUKUM ATAS POLA PENANGANAN PELANGGARAN ASAS NETRALITAS PEGAWAI NEGERI SIPIL*
}

\author{
Tedi Sudrajat ${ }^{* *}$ dan Sri Hartini***$^{* *}$
}

Bagian Hukum Administrasi Negara, Fakultas Hukum, Universitas Jenderal Soedirman

Jalan Prof. H.R. Boenyamin No. 708, Purwokerto, Jawa Tengah 53122

\begin{abstract}
The rise of legal issues on the involvement of civil servants in practical political activities shows that the regulation on civil servants was still not strong enough to prevent violations of neutrality principle in local elections. Based on that condition, this paper analyzes the legal reconstruction regarding the violation of civil servant neutrality and create appropriate mechanism dealing with the violation of neutrality principle. The study concluded that it is an urgently need to strengthen the role of government to handling violation of neutrality principle among relevant institutions' which integrated.
\end{abstract}

Keywords: neutrality principle, civil servant, violation, legal reconstruction.

\section{Intisari}

Maraknya persoalan hukum atas keterlibatan PNS dalam kegiatan politik praktis menunjukkan dengan jelas bahwa peraturan perundang-undangan di bidang kepegawaian masih belum cukup kuat untuk mencegah pelanggaran asas netralitas dalam pelaksanaan Pemilihan Umum di daerah. Atas hal tersebut, tulisan ini mengkaji tentang rekonstruksi hukum terhadap pelanggaran netralitas PNS dan membuat mekanisme yang sesuai dalam penanganan pelanggaran asas netralitas PNS. Hasil penelitian menyimpulkan bahwa diperlukannya penguatan peran pemerintah untuk mengantisipasi pelanggaran dengan pembentukan pola penanganan pelanggaran netralitas antar lembaga yang terintegrasi.

Kata Kunci: asas netralitas, Pegawai Negeri Sipil, pelanggaran, rekonstruksi hukum.

\section{Pokok Muatan}

A. Latar Belakang Masalah 447

B. Metode Penelitian 449

C. Hasil Penelitian dan Pembahasan 450

1. Rekonstruksi Hukum terhadap Pelanggaran Netralitas PNS ....................................................... 450

2. Mekanisme Penanganan Pelanggaran Netralitas PNS ................................................................... 454

D. Kesimpulan 458

Artikel ini merupakan bagian dari hasil Penelitian Hibah Bersaing tahun Ketiga yang didanai DIKTI Tahun 2016 dengan judul "Kebijakan Netralitas Politik Pegawai Negeri Sipil Dalam Pemilukada (Studi Di Jawa Tengah).

** Alamat Korespondensi: tedi.unsoed@gmail.com.

**** Alamat Korespondensi: hartini.wy@gmail.com. 


\section{A. Latar Belakang Masalah}

Reformasi yang berlangsung sejak tahun 1998 merupakan gerakan yang bertujuan menuju perubahan dalam sistem pemerintahan, salah satunya adalah perubahan di bidang pelembagaan politik dalam rangka konsolidasi demokrasi dan desentralisasi pemerintahan. Untuk dapat mensinkronasi kepentingan demokrasi, penyelenggaraan pemerintahan dan menata sistem kepegawaian maka dilakukan reformasi birokrasi yang berorientasi untuk membentuk aparatur negara yang kompeten dan profesional menuju tata pemerintahan yang baik (good governance). Atas dasar itu, sasaran perubahan reformasi adalah Pegawai Negeri Sipil (PNS) yang tugasnya bukan hanya terhenti pada tujuan-tujuan instansional yang ditetapkan oleh atasan melainkan kepada masyarakat demokratis (democratic polity). ${ }^{1}$

Peran PNS yang strategis dalam menyelenggarakan kebijakan pelayanan publik menjadi kunci keberhasilan pembangunan secara berkelanjutan. Prasyarat untuk mencapai hal tersebut adalah keberadaan PNS profesional. Adapun profesional menurut S. Tarmudji adalah "A vacation or occupation requiring advanced training in some liberal art or science and usually involving mental rather than normal work, as teaching, engineering, writing". ${ }^{2}$ Guna mewujudkan profesionalisme kerja dalam aspek kepegawaian, maka dibentuk landasan normatif dengan menciptakan daya ikat berupa sistem merit dan asas netralitas Aparatur Sipil Negara (ASN) melalui Undang-Undang No. 5 Tahun 2014 tentang ASN (UU ASN).

Secara konseptual, sistem merit berpijak pada human capital management yang didasari pada kombinasi aspek pengetahuan, keterampilan, dan kemampuan seseorang yang digunakan untuk menghasilkan layanan profesional. Konsep ini akan menjawab pemikiran bagaimana seseorang mempunyai kompetensi sesuai dengan jabatan/ posisi kerjanya dengan menempatkan insan pekerja yang bertalenta tinggi untuk menempati jabatan/ posisi yang cocok dengan talenta mereka. ${ }^{3}$ Sistem merit ini berkesesuaian dengan pembentukan asas netralitas yang dimaksudkan untuk mewujudkan kondisi obyektif dan tidak terpengaruh kepentingan dalam rangka perwujudan profesionalisme kerja. Kedua aspek inilah yang dapat membatasi dan meminimalkan intervensi kepentingan di luar tubuh PNS.

Pada saat ini, persoalan yang marak terjadi adalah masalah politisasi PNS yang bersinggungan dengan penerapan asas netralitas dalam pemilihan umum (Pemilu). Kekhawatiran publik terhadap keberpihakan PNS memang tidak berlebihan karena institusi ini sangat rentan dan mudah menjadi wilayah konflik kepentingan politis. Berdasarkan fakta sejarah, terdapat beberapa hal yang perlu dievaluasi terkait kerentanan status PNS dalam politik praktis yaitu banyaknya kasus dalam Pemilihan Umum Kepala Daerah (Pemilukada) yang menunjukkan keterlibatan PNS dalam menyukseskan salah satu pasangan calon kepala daerah didasarkan oleh adanya iming-iming promosi jabatan. Dampaknya adalah semakin buruknya kualitas pelayanan masyarakat serta semakin terpuruknya citra pemerintah karena pembangunan sistem kerja yang tidak profesional dan memihak serta menyampingkan asas netralitas. ${ }^{4}$ Contohnya di Boyolali, terdapat PNS yang menjadi tim sukses calon kepala daerah incumbent didasarkan kepentingan promosi jabatan. Badan Pengawas Pemilihan Umum (Bawaslu) menegaskan ketidaknetralan PNS di Boyolali menjadi nomor satu di Indonesia dengan diperkuat

\footnotetext{
Abdul Hamid Tome, "Reformasi Birokrasi Dalam Rangka Mewujudkan Good Governane Ditinjau dari Peraturan Menteri Pemberdayaan Aparatur Negara dan Reformasi Birokrasi Nomor 20 Tahun 2010”, Jurnal Hukum Unsrat, Vol. XX, No. 3, April-Juni 2012, hlm. 143.

S. Tarmudji, 1994, Profesionalitas Aparatur Negara Dalam Meningkatkan Pelayanan Publik, Bina Aksara, Jakarta, hlm. $20-21$.

Akhmad Aulawi, "Penerapan Sistem Merit Dalam Manajemen ASN dan Netralitas ASN dari Unsur Politik Dalam Undang-Undang Aparatur Sipil Negara", http://rechtsvinding.bphn.go.id/jurnal_online/DPR\%20P3i\%20Akhmad\%20Aulawi\%20\% 2oASN_REV.pdf, diakses 30 Juni 2016, hlm. 1-2.

Sri Hartini, et al., "Kebijakan Netralitas Politik Pegawai Negeri Sipil dalam Pemilukada (Studi di Jawa Tengah)”, Padjadjaran Jurnal Ilmu Hukum, Vol. 1, No. 3, Tahun 2014, hlm. 539.
} 
data laporan dari Panwaslu. ${ }^{5}$ Secara praktis, implikasi dari adanya keterkaitan politis antara PNS dengan Kepala Daerah terpilih adalah penempatan jabatan yang tidak berdasar kompetensi, namun lebih karena faktor marriage system bukan merit system. ${ }^{6}$ Hal inilah yang menjadi sumber persoalan dalam pembentukan karakter profesional PNS, sehingga luaran berupa independensi, obyektivitas dan transparan dalam pelayanan publik belum dapat tercapai.

Terlepas dari maraknya tindakan pelanggaran asas netralitas, ternyata pemerintah juga masih kesulitan untuk membuat formula yang tepat dalam hal penanganan pelanggaran netralitas PNS. Sumber persoalan yang diidentifikasi penulis adalah Pertama, lemahnya koordinasi antara Badan Pengawas Pemilihan Umum (Bawaslu), Komisi Pemilihan Umum Daerah (KPUD), Badan Kepegawaian Daerah (BKD) dan Dinas terkait; Kedua, Sistem kerja dari masing-masing lembaga yang tidak terintegrasi dan hanya bekerja sesuai peranan normatifnya; dan Ketiga, masih adanya celah hukum dalam proses penegakan hukum yang berimplikasi pada intervensi pejabat berwenang yang berafilisasi dengan kepentingan politik. ${ }^{7}$ Ketiga kondisi inilah yang menciptakan kurang sinergisnya pola penanganan pelanggaran netralitas PNS antara lembaga penyelenggara, pengawas dan penegak pelanggaran netralitas PNS dalam Pemilukada. Pola penanganan ini perlu direkonstruksi agar terbentuk hubungan koordinasi antar lembaga yang tidak melampaui wewenang antar lembaga, mencampuradukkan wewenang dan memberikan luaran berupa pola penanganan pelanggaran PNS yang terintegrasi sejak masuknya laporan sampai dengan diberikannya keputusan dari pejabat yang memiliki wewenang.

Berdasarkan hasil penelusuran beberapa tulisan ilmiah, pengkajian dan penulisan mengenai asas netralitas bukanlah sesuatu yang baru. Terdapat beberapa tulisan dengan obyek sejenis yang dibuat oleh M. Ardian Firnas, ${ }^{8}$ Syafuan Rozi ${ }^{9}$ dan sebagainya. Namun perbedaan mendasar dalam tulisan ini adalah fokus kajiannya dilakukan dengan pendekatan hukum bukan pendekatan ilmu sosial dan politik sebagaimana dilakukan M. Ardian Firnas dan Syafuan Rozi. Selain itu terdapat tulisan sebelumnya dari Sri Hartini, Tedi Sudrajat dan sebagainya yang menggunakan pendekatan hukum, namun kajiannya lebih mengenai pemaknaan netralitas dan sejarah pengaturan netralitas PNS, bukan mengenai pola penegakan pelanggaran asas netralitas. Atas dasar pencarian literatur tersebut, maka sejauh ini penulis belum menemukan adanya penulis lain yang membahas tentang rekonstruksi hukum atas pelanggaran netralitas PNS. Berdasarkan kondisi tersebut, maka tulisan ini memiliki arti penting untuk memperkuat eksistensi asas netralitas dan menemukan pola penanganan pelanggaran asas netralitas PNS yang bersinergi antar lembaga penyelenggara Pemilukada.

Perlu digarisbawahi bahwa pengkajian masalah penerapan pelanggaran asas netralitas telah menjadi isu hukum yang penting dan karakter persoalannya selalu berulang setiap kali penyelenggaraan Pemilu. Persoalan normatif yang perlu dicermati adalah materi muatan dalam UU ASN dan peraturan organiknya (baik yang pernah berlaku dan masih berlaku) tampaknya belum dapat sepenuhnya mencerminkan dan menemukan pola dan mekanisme penerapan pelanggaran asas netralitas yang tepat dan wajar. $^{10}$ Berdasarkan

\footnotetext{
Solo pos, "Bawaslu: Ketidaknetralan PNS Boyolali Nomor 1 di Indonesia", http://www.solopos.com/2015/12/09/pilkada-boyolali-bawasluketidaknetralan-pns-boyolali-nomor-1-di-indonesia-669108, diakses 30 Juni 2016.

Tedi Sudrajat dan Agus Mulya Karsona, "Menyoal Makna Netralitas Pegawai Negeri Sipil dalam Undang-Undang Nomor 5 Tahun 2014 tentang Aparatur Sipil Negara", Jurnal Media Hukum, Vol. 23, No. 1 Tahun 2016, hlm. 88.

Sri Hartini, et al., Kebijakan Netralitas Polik Pegawai Negeri Sipil dalam Pemilukada (Studi di Jawa Tengah), Laporan Penelitian Hibah Bersaing Tahun Kedua 2015, Purwokerto, Fakultas Hukum Universitas Jenderal Soedirman, hlm. 102.

M. Adian Firnas, "Politik dan Birokrasi: Masalah Netralitas Birokrasi Di Indonesia Era Reformasi", Jurnal Review Politik, Vol. 06, No. 01, Juni 2016.

Syafuan Rozi, 2006, Zaman Bergerak, Birokrasi Dirombak: Potret Birokrasi dan Politik di Indonesia, Pustaka Pelajar, Yogyakarta.

10 Jawa pos, "Cela Netralitas ASN", http://www.jawapos.com/read/2017/01/18/103113/celah-netralitas-asn, diakses 20 Februari 2017.
} 
kondisi tersebut, maka yang menjadi pokok permasalahan yang dikaji adalah (1) Bagaimanakah rekonstruksi hukum terhadap pelanggaran netralitas PNS? dan (2) Bagaimanakah mekanisme yang sesuai dalam rangka penanganan pelanggaran netralitas PNS ?

\section{B. Metode Penelitian}

Penelitian ini menggunakan pendekatan yuridis normatif. Penelitian dilakukan di beberapa Pemerintah Daerah di Jawa Tengah meliputi Kabupaten Banyumas, Kabupaten Boyolali, dan Kota Semarang. Walaupun obyek permasalahan dilakukan pada Pemerintah Kabupaten/Kota di Provinsi Jawa Tengah namun pola penanganan ini dapat digunakan sebagai role model pada ruang lingkup nasional. Pemilihan obyek di daerah didasarkan pada pertimbangan bahwa dalam sistem pemerintahan daerah terdapat penyerahan kewenangan berdasarkan asas otonomi untuk menyelenggarakan urusan Pemerintahan Daerah. Untuk melaksanakan urusan tersebut, diperlukan PNS sebagai pelaksana tugas pemerintahan yang fungsional-struktural berada di bawah kepemimpinan Kepala Daerah. Hal ini berarti bahwa terdapat hubungan sub ordinasi antara Kepala Daerah dengan PNS. Kondisi inilah yang dimanfaatkan oleh Kepala Daerah pada saat pelaksanaan Pemilukada guna memobilisasi bawahan dari unsur PNS untuk memilih salah satu calon. Fenomena ini terekspose pada tahun 2016, Menteri Pemberdayaan Aparatur Negara dan Reformasi Birokrasi (PAN-RB), Yuddy Chrisnandi telah menerima 56 laporan kasus penyalahgunaan wewenang yang dilakukan PNS pada pelaksanaan Pilkada Serentak 9 Desember 2015. Dari laporan tersebut, wilayah Jawa Tengah merupakan salah satu daerah yang rawan pelanggaran netralitas. ${ }^{11}$

Selain studi lapangan di Jawa Tengah, peneliti juga melakukan perbandingan hukum dengan negara lain guna menjelaskan dasar kebijakan dalam kepegawaian di negara tersebut. Pilihan untuk melakukan perbandingan dengan Singapura didasarkan atas pertimbangan bahwa Pertama, Singapura merupakan salah satu negara di Asia Tenggara yang memiliki kemajuan ekonomi yang pesat, walaupun tidak memiliki sumber daya alam ${ }^{12}$; dan Kedua, kemajuan Singapura dalam berbagai bidang di dorong oleh keberhasilan pemerintahnya dalam mengelola PNS yang efektif, efisien dan relatif bersih dari korupsi, kolusi dan nepotisme. ${ }^{13}$ Selain dari itu, Moon and Graham (1998) menyatakan bahwa, walaupun kepemimpinan dikuasai oleh politisi dan PNS di Singapura hanya mengikuti kebijakan, namun tingkat korupsi sangat rendah dan kebijakan reformasi birokrasi berjalan dengan baik. ${ }^{14} \mathrm{Hal}$ ini mengindikasikan bahwa sistem pembinaan PNS di Singapura dapat dijadikan perbandingan untuk menemukan best practises mengenai penerapan sistem merit dalam kaitannya dengan penerapan asas netralitas.

Pemahamanterhadapasasnetralitas dansistem merit di Singapura menjadi bahan perbandingan dalam menganalisis pola penerapan pelanggaran netralitas. Secara teoretis, perbandingan hukum memiliki makna sebagai landasan pemikiran dalam pembuatan aturan hukum yang didasarkan pada praktik-praktik yang berdampak pada kemanfaatan dalam pelaksanaannya. Hal ini sesuai dengan pengertian perbandingan hukum yang diartikan sebagai an intellectual activity with law as its object and comparison as its process... thus, comparative law is the comparison of the different legal system of the world. ${ }^{15}$

\footnotetext{
1 Merdeka.com, "Menteri Yuddy Ancam Pecat 56 PNS Tak Netral Saat Pilkada", https://www.merdeka.com/Peristiwa/Menteri-Yuddy-AncamPecat-56-Pns-Tak-Netral-Saat-Pilkada.Html, diakses 10 Juli 2016.

12 Berdasarkan The Global Competitiveness Report 2014-2015 World Economic Forum Geneva, Singapura berada pada peringkat 2 sedangkan Indonesia berada pada posisi 34

13 Data Political \& Economic Risk (PERC) yang dikutip dalam Assian Intteligence: An Independent Fortnightly Report on Asian Business and Politics No. 920 April 1, 2015 menyebutkan bahwa Singapura menduduki peringat 1 dengan index 1,33 dalam Persepsi Korupsi di Asean, US dan Australia, sedangkan Indonesia berada dalam 15 (kedua terburuk) dengan index 8,09 (skala 1-10).

14 Fritz M. Van der Meer (eds), 2015, Comparative Civil Service Systems in the 21st Century, Palgrave Macmillan, London, hlm. 90.

15 Konrad Zweigert dan Hein Kotz, 1992, Introduction to Comparative Law, Clarendon Press, Oxford, hlm. 2.
} 
Terhadap sampling daerah di Jawa Tengah dan pola perbandingan hukum, maka dilakukan analisis hukum dengan menggunakan logika deduktif yang disajikan secara kualitatif dengan maksud untuk menelaah kebijakan penanganan pelanggaran netralitas yang selaras dengan norma, teori dan doktrin serta aspek non hukum lainnya. Untuk menemukan makna hukumnya digunakan beberapa model interpretasi, baik secara gramatikal maupun sistematis.

\section{Hasil Penelitian dan Pembahasan}

\section{Rekonstruksi Hukum Terhadap Pelang- garan Netralitas PNS}

Secara etimologis, Rekonstruksi memiliki arti bahwa "re" berarti pembaharuan sedangkan, "konstruksi" memiliki arti suatu sistem atau bentuk. Menurut B.N Marbun, rekonstruksi adalah pengembalian sesuatu ketempatnya yang semula; penyusunan atau penggambaran kembali dari bahan-bahan yang ada dan disusun kembali sebagaimana adanya atau kejadian semula. ${ }^{16}$ Berdasarkan definisi tersebut, maka dapat penulis simpulkan bahwa maksud rekonstruksi dalam tulisan ini adalah pembaharuan dalam bidang hukum berupa pembaharuan terhadap pengaturan penanganan pelanggaran yang saat ini digunakan untuk digantikan dengan aturan main yang baru. Rekonstruksi inilah yang nantinya akan menjadi pedoman baru atau panduan dalam penanganan pelanggaran netralitas PNS yang disusun secara terintegrasi.

Dalam tataran praktis, rekonstruksi hukum terhadap asas netralitas PNS memiliki korelasi yang erat dengan penerapan sistem demokrasi modern di Indonesia. Gagasan terhadap nilai-nilai hukum dalam demokrasi modern dijelaskan oleh W. Friedmann sebagai berikut:

[...] the essential legal values of modern democracy. The first is the recognition of individual personality, whose development is protected by individual right. Of these rights those are the most essential which protect the essential personel faculties and spiritual values. Those which protect material conditions of existence rank lower and are subject to changing conditions of society. Freedom of worship and thought ranks higher than freedom of property. Individual right is balanced by responsibility towards one's fellow citizens and legal responsibility for one's acts. Democracy, secondly. demands legal protection for equel opportunity of development, regardless of personel, racial or national distinction; but the latter postulate is as yet severely limited by the organization of mankind in national states. Democracy further enjoins the law to ensure to the individual the possibility of participation in government, through adequate representation and direct responsibility. It finally demands a system of law which puts no individuals or classes above the law, guarantees its administration without distinction of persons and expresses the principle that everyone counts for one in legal rules". ${ }^{17}$

Terjemahan bebasnya sebagai berikut:

Nilai-nilai hukum yang esensial demokrasi modern, Pertama, pengakuan dari individu yang perkembangannya yang dilindungi oleh hak-hak individu. Dari hak-hak ini yang paling penting adalah melindungi kemudahan-kemudahan pribadi yang esensial dan nilai-nilai spiritual. Mereka melindungi syarat-syarat material bagi keberadaan tingkatan yang lebih rendah dan tergantung pada keadaan masyarakat yang berubah-ubah. Kebebasan beribadah dan berpikir adalah tingkatan yang lebih tinggi dari kebebasan hak untuk memiliki. Hak-hak individu adalah seimbang dengan tanggung jawab terhadap sesama warga masyarakat dan tanggung jawab hukum atas perbuatan. Kedua, demokrasi menuntut perlindungan hukum bagi kesempatan yang sama untuk pengembangan, dengan mengabaikan perbedaan pribadi, ras atau kebangsaan; akan tetapi yang disebut terakhir mandalilkan bahwa hingga kini sangat dibatasi oleh organisasi manusia di Negara nasional. Selain dari itu, Ketiga, demokrasi menyeluruh 
untuk menjamin individu yang mungkin dapat berperan serta dalam pemerintahan, melalui perwakilan yang layak dan tanggung jawab langsung. Akhirnya, Keempat, demokrasi menuntut sistem hukum yang tidak menempatkan individu atau golongan di atas hukum, menjamin administrasi tanpa perbedaan antara sesama manusia dan menetapkan prinsip bahwa setiap orang dihitung satu dalam hukum.

Berdasarkan pada pendapat W. Friedmann, dapat disimpulkan bahwa nilai-nilai hukum dalam demokrasi modern yakni: Pertama, adanya perlindungan hukum atas hak-hak individu dan masyarakat; kedua, kesempatan yang sama untuk pengembangan, dengan mengabaikan perbedaan pribadi, ras atau kebangsaan; ketiga, peran serta dalam pemerintahan baik langsung maupun melalui lembaga perwakilan; dan keempat, hukum berlaku bagi semua golongan tanpa membedakan-bedakan dalam suatu negara.

Konteks negara hukum demokratis, terdapat prinsip dasar dari pemerintahan yaitu kesetaraan atau kesamaan politik berupa setiap warga negara (termasuk PNS) memiliki hak memilih dalam Pemilu. Kondisi inilah yang menciptakan dilema dalam penyelenggaraan pemerintahan, karena memilih adalah hak, namun hak PNS tersebut dibelenggu oleh pembatasan Hak Asasi Manusia berupa penerapan asas netralitas sebagaimana diatur dalam Pasal 2 huruf f UU No.5 Tahun 2014 tentang ASN.

Implikasi dari adanya asas netralitas PNS adalah larangan:

1. Menjadi pengurus dan/anggota Partai Politik;

2. Memberikan dukungan kepada calon Presiden/Wakil Presiden, Dewan Perwakilan Rakyat, Dewan Perwakilan Daerah, atau Dewan Perwakilan Rakyat Daerah dengan cara:
a. Ikut serta sebagai pelaksana kampanye;
b. Menjadi peserta kampanye dengan menggunakan atribut partai atau atribut PNS;
c. Sebagai peserta kampanye

dengan mengerahkan PNS lain; dan/atau

d. Sebagai peserta kampanye dengan menggunakan fasilitas negara.

3. Memberikan dukungan kepada calon Presiden/Wakil Presiden dengan cara:

a. Membuat keputusan dan/atau tindakan yang menguntungkan atau merugikan salah satu pasangan calon selama masa kampanye; dan/atau

b. Mengadakan kegiatan yang mengarah kepada keberpihakan terhadap pasangan calon yang menjadi peserta pemilu sebelum, selama, dan sesudah masa kampanye meliputi pertemuan, ajakan, himbauan, seruan, atau pemberian barang kepada PNS dalam lingkungan unit kerjanya, anggota keluarga, dan masyarakat;

4. Memberikan dukungan kepada calon anggota Dewan Perwakilan Daerah atau calon Kepala Daerah/ Wakil Kepala Daerah dengan cara memberikan surat dukungan disertai foto kopi Kartu Tanda Penduduk atau Surat Keterangan Tanda Penduduk sesuai peraturan perundang-undangan; dan

5. Memberikan dukungan kepada calon Kepala Daerah/Wakil Kepala Daerah, dengan cara:

a. Terlibat dalam kegiatan kampanye untuk mendukung calon Kepala Daerah/Wakil Kepala Daerah;

b. Menggunakan fasilitas yang terkait dengan jabatan dalam kegiatan kampanye;

c. Membuat keputusan dan/atau tindakan yang menguntungkan atau merugikan salah satu pasangan calon selama masa kampanye; dan/atau

d. Mengadakan kegiatan yang mengarah kepada keberpihakan terhadap pasangan calon yang menjadi peserta pemilu sebelum, selama, dan sesudah masa kampanye meliputi pertemuan, ajakan, himbauan, 
seruan, atau pemberian barang kepada PNS dalam lingkungan unit kerjanya, anggota keluarga, dan masyarakat.

Pada prinsipnya, larangan terhadap hak berserikat dan ikut berperan serta dalam aktivitas politik merupakan implikasi dari kewajiban yang melekat pada PNS sebagai pengemban jabatan pemerintahan yang independen dan objektif. Konsep ini terdapat dalam penjelasan UU ASN bahwa dalam upaya menjaga netralitas ASN dari pengaruh partai politik dan untuk menjamin keutuhan, kekompakan, dan persatuan ASN, serta dapat memusatkan segala perhatian, pikiran, dan tenaga pada tugas yang dibebankan, ASN dilarang menjadi anggota dan/atau pengurus partai politik. Selain itu ditegaskan pula dalam penjelasan Pasal 2 huruf f UU ASN bahwa "asas netralitas" adalah setiap Pegawai ASN tidak berpihak dari segala bentuk pengaruh mana pun dan tidak memihak kepada kepentingan siapa pun.

Pengaturan tentang larangan PNS telah diatur lebih lanjut dalam Peraturan Pemerintah (PP) No. 37 Tahun 2004, PP Nomor 53 Tahun 2010 dan saat ini diatur pula dalam PP Nomor 11 Tahun 2017 tentang Manajemen PNS. Dalam praktiknya, asas netralitas sering disimpangi dalam ragam praktik aktivitas pemerintahan, antara lain:

1. Dominasi budaya patrimonial dan patriarki dalam pemerintahan. Artinya bahwa birokrasi patrimonial sebagai kelanjutan dan warisan dari nilai-nilai tradisional pada masa kerajaan masa lampau yang bercampur dengan gaya birokrasi kolonial. Saat ini, unsur etika budaya lokal atau budaya kerajaan dan budaya modern telah bercampur dalam tatanan birokrasi pemerintahan yang terus berkembang dan mewarnai lingkungan birokrasi Indonesia. Ciriciri dari birokrasi patrimonial adalah Pertama, para pejabat disaring atas dasar kriteria pribadi; Kedua, jabatan dipandang sebagai sumber kekayaan dan keuntungan; Ketiga, para pejabat mengontrol baik fungsi politik maupun fungsi administrasi dan Keempat, setiap tindakan diarahkan oleh hubungan pribadi dan politik. ${ }^{18}$

2. Masih terdapatnya kesulitan untuk membedakan antara kegiatan administratif formalistik dengan dukungan informalistik terselubung terhadap pasangan calon tertentu, khususnya yang berlangsung di luar jam dinas para PNS. Atas dasar itu, pelanggaran terhadap asas netralitas sulit untuk dibuktikan. ${ }^{19}$

Tidak dapat dipungkiri bahwa kedua ragam persoalan di atas telah menjadi pemicu dalam pelanggaran netralitas PNS dan walaupun sulit untuk ditanggulangi, namun pemerintah seharusnya dapat menciptakan mekanisme yang dapat meminimalkan persoalan pelanggaran netralitas agar tidak terjadi penyalahgunaan kekuasaan dan wewenang. Dalam logika hukum, ketika penormaan sudah terbentuk, upaya yang selanjutnya dilakukan adalah memfungsikan norma melalui penegakan hukuman. Atas dasar itu, maka konsep netralitas PNS adalah memberikan pembatasan dan kepastian akan peran dari PNS dalam pemerintahan. Adapun implikasi pembatasan adalah penegakan hukum yang berorientasi pada kepastian hukum bagi seluruh PNS untuk melaksanakan tugas secara profesional. $^{20}$

Sebagai bahan perbandingan dalam penerapan asas netralitas PNS, Pemerintah Singapura telah mengantisipasi pelanggaran

\footnotetext{
18 Lili Ramli, "Masalah Reformasi Birokrasi”, Civil Service, Jurnal Kebijakan dan Manajemen PNS, Vol 11 No. 2 November 2008; Lihat pula dalam Hayat, "Konsep kepemimpinan Dalam Reformasi Birokrasi: Aktualisasi Pemimpin Dalam Pelayanan Publik Menuju Good Governance",Jurnal Borneo Administrator, Vol. 10, No. 1, April 2014, hlm. 72.

19 Mat Zudi, et al., "Netralitas Pegawai Negeri Sipil Dalam Pemilihan Kepala Daerah”, Diponegoro Law Review, Vol. 1, No. 4, Tahun 2012, hlm. 2.

20 Tedi Sudrajat dan Agus Mulya Karsona, Op.cit., hlm. 93.
} 
wewenang dengan menerapkan sistem merit yang berbasis kinerja serta didukung oleh kepemimpinan yang kuat. Regulasi di Singapura telah membatasi hubungan antara PNS dengan pejabat politik untuk meminimalkan pelanggaran melalui Code of Conduct For Ministers Tahun 2005. Dalam Pasal 4 bagian Relations with civil servants disebutkan bahwa: ${ }^{21}$

4.1 A Minister must not use his influence to support the candidature of any person for admission to or promotion within the Singapore Civil Service. However, a Minister may give a person known personally to him a written testimonial for first appointment to the Singapore Civil Service.

4.2 Where a Minister is familiar with the work of a civil servant and his opinion is sought by the Public Service Commission or Public Service Division for the purposes of appraising the civil servant's performance, the Minister may render his opinion on the matter.

4.3 A Minister must not direct or request a civil servant to do anything or perform any function that may conflict with the Singapore Civil Service's core values of incorruptibility, impartiality, integrity and honesty. He should respect the duty of civil servants to remain neutral in all political matters and matters of public controversy.

Mencermati pasal 4 Code Of Conduct For Ministers, pembatasan hubungan antara PNS dengan pejabat politik dilakukan secara profesional. Hal ini berarti bahwa tidak adanya celah yang memperbolehkan pejabat politik memberikan pengaruh terhadap kedudukan dari PNS. Hal ini menegaskan bahwa terdapat larangan bagi pejabat politik untuk mengarahkan atau meminta PNS untuk melakukan sesuatu atau melakukan fungsi yang bertentangan dengan nilai-nilai pelayanan publik seperti halnya korupsi, imparsialitas, integritas dan kejujuran. Dalam kaitan ini, pejabat politik juga harus menghormati tugas PNS untuk tetap netral dalam segala hal politik dan hal-hal kontroversi publik.
Konteks Indonesia saat ini, posisi PNS berada dalam sistem yang terkoneksi dengan kepentingan politik. Di dalam sistem ini masih terdapat hubungan yang bersinergi antara Kepala Negara/ Kepala Daerah dengan PNS dalam lingkungan kerja yang saling berpengaruh. Apalagi hubungan ini menimbulkan implikasi jabatan karier PNS atas dasar kewenangan Kepala Negara/Daerah sebagai Pejabat Pembina Kepegawaian Daerah (PPKD) yang memiliki wewenang untuk menetapkan pengangkatan, pemindahan dan pemberhentian PNS. Jelas, kondisi ini akan mengakibatkan ketidaknetralan PNS dalam melaksanakan tugas karena dalam pelaksanaan tugas pemerintahan terkandung hubungan antara yang memerintah dengan yang diperintah.

Selain dari persoalan di atas, pada saat ini mekanisme penanganan pelanggaran asas netralitas di Indonesia memiliki kelemahan berupa tidak masuknya lembaga pelaksana Pemilu yaitu Komisi Pemilihan Umum Daerah (KPUD) dan Bawaslu Provinsi dan Panwaslu Kabupaten/Kota dalam struktur penegakan hukumannya. Pada dasarnya, keberadaan dari KPUD menjadi sentral dalam penegakan netralitas PNS didasarkan pada fungsi KPUD sebagai penyelenggara pemilihan Umum yang memiliki tugas mengoordinasikan, menyelenggarakan dan mengendalikan seluruh tahapan kegiatan pemilihan umum agar sesuai dengan peraturan perundang-undangan. Adapun Bawaslu Provinsi dan Panwaslu Kabupaten/Kota merupakan garda terdepan yang bertugas mengawasi penyelenggaraan Pemilu dalam rangka pencegahan dan penindakan pelanggaran untuk terwujudnya Pemilu yang demokratis, termasuk di dalamnya adalah memastikan tidak adanya pelanggaran asas netralitas PNS. Terhadap kondisi tersebut, terdapat 2 (dua) persoalan dalam penanganan pelanggaran netralitas PNS saat ini yaitu:

1. Pola penegakan pelanggaran PNS masih bermuara pada Badan kepegawaian Daerah (BKD), Badan Kepegawaian

21 Article 4 Code Of Conduct For Ministers of Singapore. 
Negara $(\mathrm{BKN})$ dan Komisi Aparatur Sipil Negara (KASN). Pola ini mengakibatkan penanganan yang tidak terintegrasi dan pemahaman persoalan (kasus pelanggaran netralitas) yang tidak menyeluruh (parsial). Kondisi ini dimungkinkan terjadi karena yang menerima laporan pelanggaran netralitas PNS bukan hanya BKD, namun bisa juga dari KPUD, Bawaslu Provinsi dan Panwaslu Kabupaten/ Kota; dan

2. Mekanisme penjatuhan hukuman yang masih diserahkan sepenuhnya pada pejabat internal kepegawaian (PPKD), sehingga mekanisme penilaian dan pengawasan pelanggaran menjadi tidak transparan dan ukuran keberhasilannya menjadi tidak jelas. Atas dasar itu, maka diperlukan mekanisme baru yang dapat mengintegrasikan lembaga terkait pelanggaran netralitas untuk masuk menjadi unsur pengawas, penilai dan penjatuhan hukuman dalam pelanggaran netralitas.

Terhadap persoalan tersebut, diperlukan rekonstruksi hukum terhadap pola penanganan pelanggaran netralitas dengan cara menghidupkan dan mengintegrasikan kewenangan antar lembaga dengan memperkuat pada fungsi koordinasi antara lembaga penyelenggara Pemilu, pengawas Pemilu, penyelenggara pemerintahan dan lembaga yang memutuskan hukuman pelanggaran netralitas PNS. Hal ini berarti bahwa KPUD dan Panwaslu diberikan wewenang untuk ikut terlibat aktif dalam proses pelaporan, pengawasan dan penyelidikan dari PNS yang diduga melakukan pelanggaran netralitas. Terhadap kondisi tersebut, maka prinsip ini akan mengangkat signifikansi kewenangan lembaga seperti Komisi Aparatur Sipil Negara (KASN), BKD, BKN, Inspektorat, Bawaslu
Provinsi dan Panwaslu Kabupaten/Kota dan KPUD dalam keterlibatan untuk menegakkan dan menjaga integritas penyelenggaraan Pemilu yang berintegritas.

\section{Mekanisme Penanganan Pelanggaran Netralitas PNS}

Hakikatnya, netralitas PNS dalam kegiatan politik tidak dapat terlepas dari paradigma yang mendikotomikan antara administrasi dan politik yang dikembangkan oleh Woodrow Wilson. Menurut Wilson, administrasi negara atau PNS berfungsi melaksanakan kebijaksanaan politik bahwa administrasi atau PNS berada di luar kajian politik, dan persoalan-persoalan administrasi bukanlah dalam ranah politik. $^{22}$ Konsep Wilson tersebut dikuatkan oleh Frank Goodnow yang mengajarkan bahwa terdapat dua fungsi pokok pemerintah yang sangat berbeda satu sama lain, yaitu politik dan administrasi. Politik adalah pihak yang berkewajiban membuat dan merumuskan kebijakan, sementara administrasi berhubungan dengan pelaksanaan kebijakan tersebut. ${ }^{23}$

Berdasarkan makna di atas, maka seharusnya yang dimaksud dengan definisi netral adalah suatu kondisi seseorang yang tidak memihak dan tidak memiliki sikap tertentu kepada orang lain atau pihak tertentu, atau dapat disebut juga dengan suatu kondisi seseorang yang tidak mendapatkan pengaruh dari pihak mana pun di luar dirinya. Mengacu pada esensi netralitas, dapat dinyatakan bahwa dalam netralitas PNS hanya diarahkan untuk melaksanakan tugas dan fungsinya dalam penyelenggaraan pemerintahan, pembangunan, dan pelayanan kepada masyarakat, tanpa ikut serta dalam kegiatan politik (apolitic). Hal ini berarti bahwa netralitas tidaklah berdiri dalam ruang hampa, namun berkorelasi dengan esensi obyektivitas, karena hakikat akan obyektivitas selalu bermuara pada kondisi netral, maka jelas bahwa substansi netral adalah tidak memihak. Sejatinya, kondisi tidak memihak akan terpenuhi jika berada di luar sistem dan tidak

\footnotetext{
Woodrow Wilson dalam Warsito Utomo, 2006, Administrasi Publik Baru Indonesia: Perubahan Paradigma dari Administrasi Negara ke Administrasi Publik, Pustaka Pelajar, Yogayakarta, hlm. 6.

23 Frank Goodnow dalam Warsito Utomo, Loc.cit.

24 Tedi Sudrajat dan Agus Mulya Karsona, Op.cit, hlm. 92.
} 
memberikan ruang akan intervensi kepentingan. ${ }^{24}$

Mencermati makna netralitas, maka maksud dari pembentukan pola penanganan pelanggaran netralitas yang terintegrasi adalah untuk merancang pola yang sistematis terhadap penanganan pelanggaran netralitas PNS yang wajar dan proporsional, sesuai dengan wewenangnya. Di dalam perancangan pola tersebut, Pemerintah harus mampu membangun keseimbangan (homeostasis) kepentingan para pihak yang menjadi tujuan dibuatnya kebijakan tersebut. Keseimbangan sangat penting, karena menyangkut 2 (dua) sifat dasar manusia yaitu manusia sebagai Homo Economicus dan manusia sebagai Homo Juridicus. Sebagai Homo Economicus, manusia dalam hidupnya selalu menggunakan prinsip-prinsip ekonomi. Sebagai Homo Juridicus, manusia dalam hidupnya selalu menggunakan prinsip-prinsip hukum. Manusia ingin mendapatkan ketenteraman, ketenangan dan kepastian terhadap hak dan kewajibannya sebagai warga negara. Oleh karena itu, pada saat negara mengatur, haruslah dapat menciptakan keseimbangan kedudukan manusia sebagai homo economicus dan juridicus. ${ }^{25} \mathrm{Hal}$ ini berarti bahwa pola penegakan hukum seharusnya memperbedakan antara subyek yang homogen dan yang majemuk (bhinneka). Pada masyarakat majemuk, politik hukum penegakan hukum yang serba menyamakan (uniformitas) dapat menimbulkan masalah politik, ekonomi maupun sosial. Karena itu politik hukum seperti unifikasi harus dipertimbangkan dengan matang kemanfaatannya pada masyarakat majemuk (heterogen). ${ }^{26}$

Pola penegakan hukum yang didasarkan pada kasus yang heterogen memerlukan penanganan kasus yang berbasis pada fakta. Atas dasar itu, maka pemerintah harus dapat mengakomodasi keseimbangan kepentingan melalui penguatan terhadap alat bukti pelanggaran netralitas yang cukup dan cover both side. Implikasinya adalah pembentukan mekanisme baru dengan cara melakukan koordinasi antar lembaga yang terkait dengan penegakan hukuman netralitas PNS dengan mengikutsertakan BKD, Inspektorat, KPUD, Bawaslu/Pawaslu dan Masyarakat. Sinergisme dalam pola penegakan hukum akan menciptakan efektivitas penegakan hukumannya. Hal ini dapat

\section{Bagan 1. Pola Penegakan Hukum Netralitas PNS}

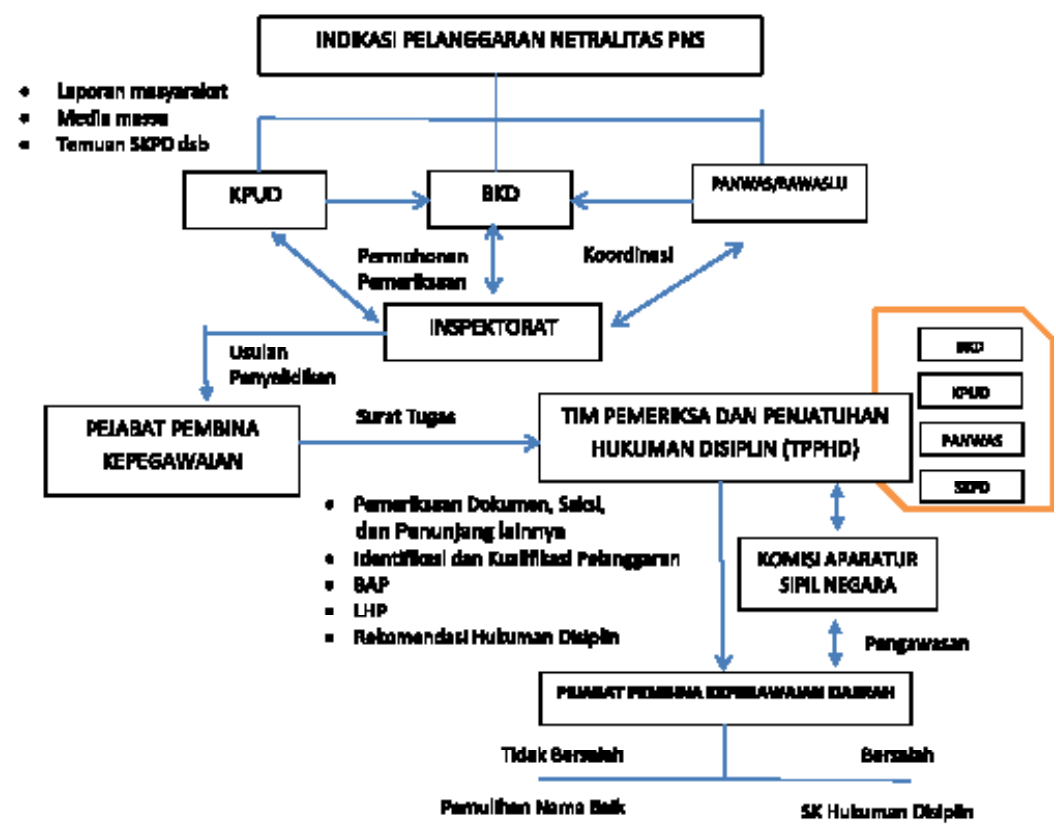

Sumber: Diolah Penulis, 2017.

25 Zudan Arif Fakrulloh, "Kedudukan Peraturan Daerah Dalam Pelaksanaan Otonomi Daerah dan Pembangunan Substansi Hukum di Daerah", Majalah Hukum Nasional, 2000, hlm. 99.

26 Abrar Saleng, "Penegakan Hukum dalam Era Reformasi", Jurnal Hukum Ius Quia Iustum, Vol. 11 No. 25, Januari 2004 , hlm. 155. 
terlihat dalam bagan 1 .

Bagan 1 menjelaskan bahwa terdapat beberapa tahapan yang harus dilewati dalam melakukan pengawasan, penyelidikan dan memutuskan hukuman atas pelanggaran netralitas PNS, berupa:

1. Fungsi pelaporan melekat pada BKD, KPUD dan Panwas/Bawaslu. Hal ini memberikan penjelasan bahwa masyarakat dapat melaporkan pelanggaran netralitas kepada ketiga lembaga tersebut. Semakin banyak sarana pelaporan dan semakin dipermudah dalam proses pelaporan pelanggaran, maka efektivitas penegakan hukuman akan semakin baik;

2. Dalam hal permohonan pemeriksaan atas pelanggaran, maka perlu dilakukan koordinasi dengan pihak Inspektorat guna mengkonfirmasi alat bukti pelaporan, baik yang diterima oleh BKD, Panwas/Bawaslu ataupun dari KPUD;

3. Secara kelembagaan, proses penyelidikan atas pelanggaran netralitas memerlukan lembaga khusus yang ditetapkan oleh Kepala Daerah (PPKD) melalui Tim Pemeriksa dan Penjatuhan Hukuman Disiplin (TPPHD) yang terdiri dari unsur KPUD, Panwas/ Bawaslu, Inspektorat, SKPD yang PNSnya dilaporkan melanggar asas netralitas dan unsur BKD. Fungsi dari TPPHD adalah melakukan proses penyelidikan secara menyeluruh atas laporan pelanggaran yang diawasi oleh KASN;

4. Ketika terdapat usulan penjatuhan hukuman dari TPPHD, maka sesuai dengan wewenangnya PPKD menjatuhkan Hukuman terhadap pelanggar. Bentuk pengawasan tetap dilaksanakan oleh KASN dalam rangka menciptakan obyektivitas dalam penjatuhan hukuman.

Tugas masing-masing lembaga dan mekanisme penjatuhan hukuman atas pelanggaran netralitas PNS dapat dapat dijelaskan lebih rinci dalam tabel di bawah ini:

Tabel 1. Mekanisme Penyelesaian

\begin{tabular}{|c|c|c|c|c|c|}
\hline \multirow[t]{2}{*}{ Jenis } & \multirow{2}{*}{$\begin{array}{c}\text { Ruang } \\
\text { Lingkup }\end{array}$} & \multicolumn{4}{|c|}{ Mekanisme Penyelesaian } \\
\hline & & Diterima & Diproses & $\begin{array}{c}\text { Badan Yang } \\
\text { Memutus }\end{array}$ & $\begin{array}{l}\text { Lembaga } \\
\text { Pengawas }\end{array}$ \\
\hline $\begin{array}{l}\text { Pelanggaran } \\
\text { Netralitas }\end{array}$ & Daerah & $\begin{array}{l}\text { KPUD/Panwaslu/ } \\
\text { Bawaslu/BKD } \\
\text { menerima laporan } \\
\text { dan/atau temuan } \\
\text { terhadap pelanggaran } \\
\text { netralitas PNS }\end{array}$ & $\begin{array}{l}\text { TPPHD yang } \\
\text { meliputi KPUD/ } \\
\text { Panwaslu/ } \\
\text { Bawaslu /BKD } \\
\text { menindaklanjuti } \\
\text { laporan adan/atau } \\
\text { temuan }\end{array}$ & $\begin{array}{l}\text { PPKD } \\
\text { memutus } \\
\text { perkara } \\
\text { pelanggaran } \\
\text { pelanggaran } \\
\text { kode etik dan } \\
\text { kode perilaku } \\
\text { Pegawai ASN }\end{array}$ & $\begin{array}{l}\text { KASN me- } \\
\text { nyampaikan } \\
\text { rekomendasi } \\
\text { kepada Presi- } \\
\text { den terkait } \\
\text { Keputusan } \\
\text { KASN } \\
\text { yang tidak } \\
\text { ditindaklanju } \\
\text { ti oleh Pejabat } \\
\text { Pembina } \\
\text { Kepegawaian }\end{array}$ \\
\hline
\end{tabular}

Sumber: Diolah Penulis, 2017.

Pada dasarnya, pola penanganan pelanggaran netralitas PNS merupakan bagian dari penegakan Hukum Administrasi Negara yang dilakukan secara represif dan memiliki sifat reparatoir condemnatoir. Namun untuk dapat meminimalkan terjadinya pelanggaran, maka diperlukan pula pola pengawasan secara preventif dalam penerapan asas netralitas PNS yang mengacu pada prinsip negara hukum demokratis berupa:

1. Pemerintah harus selalu menjaga iklim kondusif dan memberikan kesempatan kepada para PNS untuk melaksanakan 
hak pilihnya secara bebas dengan tetap menjaga netralitas, serta tidak menghalang-halangi atau melakukan mobilisasi PNS di lingkungannya;

2. Pemerintah melakukan pengawasan terhadap bawahannya sebelum, selama dan sesudah masa kampanye Pemilu, agar tetap menaati peraturan perundang-undangan dan ketentuan kedinasan yang berlaku; dan

3. Mengambil tindakan dengan melaporkan dan mengkoordinasikan kepada lembaga Pengawas Pemilu secara berjenjang sesuai kewenangannya serta memproses penjatuhan sanksi hukuman disiplin atau tindakan administratif, apabila mengetahui adanya PNS yang melakukan pelanggaran.

Dalam kerangka mengintegrasikan penanganan pelanggaran netralitas PNS, maka penulis mengajukan 6 (enam) prinsip yang dapat dijadikan sebagai batasan dan kriteria dalam pelaksanaan asas netralitas bagi PNS, meliputi:

1. Politik dan kebijakan berbeda dengan administrasi. Politik menciptakan kebijakan, sedangkan pegawai ASN menjalankan kebijakan;

2. PegawaiASN dipilih dan dipromosikan berdasarkan sistem merit daripada kedekatan hubungan dan kepentingan politik serta kontribusinya terhadap partai politik;

3. Pegawai ASN tidak terikat dan tidak boleh terlibat dalam setiap kegiatan politik praktis;

4. Pegawai ASN tidak boleh mengungkapkan secara terbuka mengenai pandangan pribadinya terhadap kebijakan yang dikeluarkan pemerintah;

5. Ketika terdapat masukan terhadap kebijakan, Pegawai ASN memberikan saran secara langsung, jelas dan objektif kepada pemerintah; dan

6. Pegawai ASN menerima dan melaksanakan keputusan terhadap setiap kebijakan, terlepas dari kepentingan politik yang berkuasa dan pendapat pribadi mereka.

Atas dasar 6 (enam) prinsip di atas, maka netralitas politik bagi PNS dapat diberlakukan sangat ketat melalui kebijakan:

a. PNS menjadi non-partisan;

b. PNS tidak melakukan pekerjaan yang bermanfaat bagi salah satu pihak; dan

c. Pegawai negeri senior dibatasi dari mengambil bagian dalam partai politik bahkan di luar peran profesional mereka.

Tiga kebijakan tersebut harus pula dinetralkan dengan adanya keseimbangan hubungan antara kegiatan politik dan pegawai ASN melalui komitmen pengawasan berupa :

1. Administrators support the law, respect political supremacy, and acknowledge the need for accountability.

2. Administrators are responsible for serving the public and supporting the democratic process.

3. Administrators are independent with the commitment to professional values and competence, and they loyal to the mission of their agency.

4. Administrators are honest in their dealing with elected officilas, seek to promote the broadest conception of public interest and act in an ethcal grounded way.

5. Elected officials respect the contribution of professional administrators and integrity of the administrative process. ${ }^{27}$

Mencermati upaya preventif dan represif yang sepatutnya dilakukan oleh Pemerintah, maka pola penanganan pelanggaran netralitas PNS dapat menjadi strategis ketika aspek profesionalisme pegawai terkoneksi dengan pengaturan yang membatasi masuknya kepentingan dalam penyelenggaraan tugas kedinasan oleh PNS.

\footnotetext{
27 James H Svara, "Complexy in Political-Administrative Relations and The Limits of The Dichotomy Concept", Journal of Administrative
} Theory \& Praxis, Vol. 28, No. 1, 2006, hlm. 133. 


\section{Kesimpulan}

Pelanggaran netralitas PNS merupakan isu hukum yang selalu terjadi di setiap penyelenggaraan Pemilu. Persoalan menahun ini akan dapat terselesaikan melalui komitmen pemerintah untuk membatasi PNS dalam kegiatan politik praktis. Kondisi ini menuntut akan rekonstruksi hukum terhadap pola penanganan pelanggaran PNS melalui 2 (dua) upaya, baik secara represif maupun preventif. Upaya represif dilakukan dengan cara membuat pengaturan tentang pola penanganan pelanggaran netralitas PNS dengan memperkuat pada fungsi koordinasi antara lembaga penyelenggara Pemilu, pengawas Pemilu, penyelenggara pemerintahan dan lembaga yang memutuskan hukuman pelanggaran netralitas PNS. Adapun upaya preventif dilakukan dengan cara penguatan peran pemerintah untuk mengantisipasi sifat pelanggaran, meliputi Pertama, menjaga iklim kondusif dan memberikan kesempatan kepada PNS untuk melaksanakan hak pilihnya secara bebas dengan tetap menjaga netralitas, serta tidak melakukan mobilisasi PNS di lingkungannya; dan Kedua, setiap jenjang jabatan melakukan pengawasan terhadap bawahannya sebelum, selama dan sesudah masa kampanye Pemilu.
Mekanisme yang seharusnya dilakukan oleh pemerintah adalah membuat pentahapan kegiatan sejak pelaporan, pengawasan, penyelidikan dan memutuskan hukuman atas pelanggaran netralitas PNS. Fungsi pelaporan dan pengawasan dilekatkan pada beberapa lembaga seperti halnya BKD, KPUD dan Panwas/Bawaslu dengan cara menginventarisasi, mengidentifikasi laporan dari masyarakat dan melakukan fungsi pengawasan melekat secara berjenjang. Proses penyelidikan dilakukan dengan membuat lembaga khusus yang ditetapkan oleh PPKD yang berbentuk TPPHD yang terdiri dari unsur KPUD, Panwas/Bawaslu, Inspektorat, SKPD yang PNSnya dilaporkan melanggar asas netralitas dan unsur BKD. TPPHD difungsikan untuk menemukan jenis pelanggaran netralitas dan merekomendasi hukuman disiplin yang sesuai dengan jenis pelanggarannya. Keberadaan dari pola penanganan ini dapat diwujudkan dengan pembentukan peraturan bersama antara Badan Kepegawaian Negara, KPU dan Bawaslu. Peran ketiga unsur kelembagaan dimaksudkan untuk meminimalkan perbenturan kepentingan di tingkat eksekutif untuk menemukan pelanggaran berdasarkan fakta yang terjadi di lapangan.

\section{DAFTAR PUSTAKA}

\section{A. Buku}

Friedmann, W., 1967, Legal Theory, Fifth Edition, Steven and Sons, New York.

Marbun, B.N., 1996, Kamus Politik, Pustaka Sinar Harapan, Jakarta.

Meer, Fritz M. Van der (eds), 2015, Comparative Civil Service Systems in the 21st Century, Palgrave Macmillan, London.

Rozi, Syafuan, 2006, Zaman Bergerak, Birokrasi Dirombak: Potret Birokrasi dan Politik Di Indonesia, Pustaka Pelajar, Yogyakarta.

Tarmudji, S., 1994, Profesionalitas Aparatur Negara Dalam Meningkatkan Pelayanan Publik, Bina Aksara, Jakarta.
Utomo, Warsito, 2006, Administrasi Publik Baru Indonesia; Perubahan Paradigma dari Administrasi Negara ke Administrasi Publik, Pustaka Pelajar, Yogyakarta.

Zweigert, Konrad and Hein Kotz, 1992, Introduction

to Comparative Law, Clarendon Press, Oxford.

\section{B. Artikel Jurnal}

Firnas, M. Adian, "Politik dan Birokrasi: Masalah Netralitas Birokrasi Di Indonesia Era Reformasi”, Jurnal Review Politik, Vol. 06, No. 01 Juni 2016.

Hartini, Sri, et al., "Kebijakan Netralitas Politik 
Pegawai Negeri Sipil dalam Pemilukada (Studi di Jawa Tengah)", Padjadjaran Jurnal Ilmu Hukum, Vol. 1, No. 3, Tahun 2014.

Ramli, Lili, "Masalah Reformasi Birokrasi”, Civil Service, Jurnal Kebijakan dan Manajemen PNS, Vol. 11 No. 2, November 2008.

Saleng, Abrar, "Penegakan Hukum dalam Era Reformasi”, Jurnal Hukum Ius Quia Iustum, Vol. 11 No. 25, Januari 2004.

Sudrajat, Tedi dan Karsona, Agus Mulya, "Menyoal Makna Netralitas Pegawai Negeri Sipil dalam Undang-Undang Nomor 5 Tahun 2014 tentang Aparatur Sipil Negara", Jurnal Media Hukum, Vol. 23, No. 1, Tahun 2016.

Svara, James H, "Complexy in PoliticalAdministrative Relations and The Limits of The Dichotomy Concept", Journal of Administrative Theory \& Praxi, Vol. 28 No. 1, 2006.

Tome, Abdul Hamid, "Reformasi Birokrasi Dalam Rangka Mewujudkan Good Governane Ditinjau dari Peraturan Menteri Pemberdayaan Aparatur Negara dan Reformasi Birokrasi Nomor 20 Tahun 2010", Jurnal Hukum Unsrat, Vol. XX No. 3, AprilJuni 2012.

Zudi, Mat; Hidayat, Arief; Hardjanto, Untung Sri, "Netralitas Pegawai Negeri Sipil Dalam Pemilihan Kepala Daerah", Diponegoro Law Review, Vol. 1 No. 4, Tahun 2012.

\section{Majalah/Koran/Penelitian}

Fakrulloh, Zudan Arif, Kedudukan Peraturan Daerah Dalam Pelaksanaan Otonomi Daerah dan Pembangunan Substansi Hukum di Daerah, Majalah Hukum Nasional, 2000.

Hartini, Sri; Kadarsih, Setiajeng dan Sudrajat, Tedi, Kebijakan Netralitas Polik Pegawai Negeri Sipil dalam Pemilukada (Studi di Jawa Tengah), Laporan Penelitian Hibah Bersaing Tahun Kedua 2015, Purwokerto, Fakultas Hukum Universitas Jenderal Soedirman.

\section{Internet}

Aulawi, Akhmad, "Penerapan Sistem Merit Dalam Manajemen ASN dan Netralitas ASN dari Unsur Politik Dalam Undang-Undang Aparatur Sipil Negara", http://rechtsvinding. bphn.go.id/jurnal_online/DPR\%20P3i\%20 Akhmad\%20Aulawi\%20\% 2oASN_REV.pdf., diakses 30 Juni 2017.

Jawa pos, "Celah Netralitas ASN", http://www. jawapos.com/read/2017/01/18/ 103113/ celah-netralitas-asn, diakses 20 Februari 2017.

Merdeka.com, "Menteri Yuddy Ancam Pecat 56 PNS Tak Netral Saat Pilkada", https://www. merdeka.com/Peristiwa/Menteri-YuddyAncam-Pecat-56-Pns-Tak-Netral-SaatPilkada.Html, diakses 10 Juli 2016.

Solo Poss, "Bawaslu: Ketidaknetralan PNS Boyolali Nomor 1 di Indonesia", http://www.solopos. com/2015/12/09/pilkada-boyolali-bawasluketidaknetralan-pns-boyolali-nomor-1-diindonesia-669108, diakses 30 Juni 2016.

\section{E. Peraturan Perundang-undangan}

Undang-Undang Dasar Negara Republik Indonesia Tahun 1945.

Undang-Undang Nomor 5 Tahun 2014 tentang Aparatur Sipil Negara (Lembaran Negara Republik Indonesia Tahun 2014 Nomor 6, Tambahan Lembaran Negara Republik Indonesia Nomor 5494).

Undang-Undang Nomor 23 Tahun 2014 tentang Pemerintahan Daerah (Lembaran Negara Republik Indonesia Tahun 2014 Nomor 244, Tambahan Lembaran Negara Republik Indonesia Nomor 5587) sebagaimana telah diubah beberapa kali, terakhir dengan Undang-Undang Nomor 9 Tahun 2015 tentang Perubahan Kedua atas UndangUndang Nomor 23 Tahun 2014 tentang Pemerintahan Daerah (Lembaran Negara Republik Indonesia Tahun 2015 Nomor 58, Tambahan Lembaran Negara Republik Indonesia Nomor 5679). 
Peraturan Pemerintah Nomor 37 Tahun 2004 tentang Larangan Pegawai Negeri Sipil Menjadi Anggota Partai Politik (Lembaran Negara Republik Indonesia Tahun 2004 Nomor 128, Tambahan Lembaran Negara
Republik Indonesia Nomor 4440).

Peraturan Pemerintah Nomor 53 Tahun 2010 tentang Disiplin Pegawai Negeri Sipil (Lembaran Negara Tahun 2010 Nomor 74, Tambahan Lembaran Negara Nomor 5135). 